【特 集：衣類とごみ一おしゃれと環境一】

\title{
衣類などのリユースショップを資源に太陽光発電所作り
}

\author{
新 藤 絹 代 *
}

\section{1. 転機となったチェルノブイリ事故}

子どもにアレルギーがあったこともあり，添加物の少 ない食べ物・低農薬の野菜を食べたいと思い生協に加入 し，食べ物にこだわり組合員活動にも参加してきた。

1986 年に思わ好事件が起った。私たちの生活クラブ 生協のお茶は三重県の度会（わたらい）で作っているが, その年採れた扰茶から通常を上回る $1 \mathrm{~kg}$ あたり 227 ベ クレルの放射能が検出されたのである。これは国の基準 の 370 ベクレルよりは低く一般市場では安全といわれる ものであるが, 私たちの生協では国の基準より厳しい自 主基準 37 ベクレルを決めていたことから，この抧茶は 出荷停止になってしまった。その年の 4 月 26 日に起っ たチェルノブイリ原子力発電所の事故により，はるか $8,000 \mathrm{~km}$ はなれた日本にまで污染が広がっていたので ある。峦は 5 月に刈り取られるので, ちょうど刈り取 り前に降った雨に放射能が含まれていたと考元られる。 㧍茶の生産者は, これまで農林大臣賞を何度か受けた茶 づくりの名人といわれる方である。土づくりから水にま で気を配って打茶を作ってこられた。私たち組合員も 洗って使うことのできない抢茶の安全性にはこだわりが あったのである。

ひとたび地球上のどこかの原子力発電所で事故が起れ ば，自分だけで安心・安全な食べ物は作れないのだとい うことに気がついた。当時は，干草ではなく牧草を食べ た牛の牛乳, ハウス栽培より露地栽培の野菜に, より多 くの放射能が検出され，まさに青天の霹靂という気がし た。原子力発電所をなくさない限り安全な食べ物はない と気がついた。日本から見て地球の反対側ともいえると ころで起った事故でこのような影響を受けるのだから， 発電所近くの放射能污染と惨状はどのようなものだった

原稿受付 2010.4.2

* 特定非営利活動法人エコメッセ

連絡先： $\overline{1} 177-0052$ 練馬区関町東 1-24-5「元気力発電所」関町店 E-mail : shindo-f@olive.plala.or.jp
のであろうか。考えるだけで恐ろしくなる。

\section{2. 環境団体エコメッセの設立}

けれども，原子力発電所に「反対」「反対」といって いても，私たちが今の快適な生活を変えない限り，多く のエネルギーを使い電気や石油・原子力に依存した生活 が続いていくであろう。そこで，石油や原子力に代わる エネルギーとして, 少しでも太陽光や風力などの自然工 ネルギーに変えていけば，いずれ限りある原子力や化石 燃料に依存する生活を変えられるのではないかと思い, 地域の身近なところでの自然エネルギーの普及と, 省工 ネルギーを広げる活動を始めた。ドイッが脱原発から再 生可能エネルギーへの変換を法律で決めた動きや市民の 電力会社を作る運動を知り，勇気を与えられた。

活動には，「人」と「扔金」が必要である。「人」はこ れまで生協活動をともにしてきた仲間に呼びかけた。資 金源としてリユースショップを開くことで，資金を得る だけではなく，衣類や雑貨のリユースを通じてものを大 切にすることも提案でき, 多くの人との情報交換も, 店 という場でできるのではないかと考えた。これは以前滞 在したイギリスの NGO OXFAM の活動にヒントを得た ものである。

店の屋号は『原子力発電所』に対して『元気力発電 所』とした。

\section{3. リユースショップ『元気力発電所』から見 た衣類リサイクル事情}

店を始めてすぐに気付いたことは，いかに各家庭に着 なくなった衣類が多いかということである。どうみても 何 10 年経ったと思われるものもある。皆さん, ごみと しては捨てられないので保管している。けれども何年も 着ていない。人にさし上げるのも好みがあるし, 失礼か も。そんな時, われわれの店に持って行くと何やら役に 立てていただけるという『良いことした感』があるので 
はと思っている。

われわれの店はすべて寄付によるものである。よく町 にあるリサイクルショップと違い, 買い取りでもなけれ ば委託でもないので，当初はものが集まるか心配したが, 思った以上に地域の環境活動に使いたいという趣旨を理 解していただけたようで, 寄付でもいろんなものがたく さんいただけた（表 1)。買い取りや委託だと, 昔の『質 屋』のイメージだけれど，われわれの店は自分がささや かながら社会の役に立っているという気持ちも味わって いただけるのである。買ってくださる人も，買い物をし たいという人間としての欲望を低価格で満足でき, 普段 着ないような色やデザインのものを試してみるなど冒険 もできる。しかも売上が地域の環境活動『市民発電所建
設』という目にみえた形になる。

だから，ここで買うのよというお客も，全員ではない にしてもいらっしゃる（表2）。

一方困ったことも出てきた。すべてものが，季節に合 わせて順調に全部売れるわけではないので, 残ったもの をどうするかということである。リユースショップは仕 入れがないので, 良いもの, 気に入ったものを手に入れ たい拈客さんは毎日のように店を訪れる。そのような 人々のためにも同じものを長期間展示しておくわけには いかないことにも気付いた。そのため練馬に相次いで 3 店舗作り, こまめにそれぞれの店のものを循環させるこ ともした。けれど季節により必要とされる衣類は違い, 店に長期間展示されることにより季節外れになっていく。

\section{表 1 年間品物提供者数}

2008 年度店舗別品物提供数

単位：件

\begin{tabular}{|r|r|r|r|r|r|r|r|r|r|r|r|r|r|r|}
\hline & 関町店 & 練馬店 & 石神井 & 江戸川 & 千船1 & 千船(2) & 学大店 & 池尻店 & 昭島店 & 田無店 & 多摩店 & 八王子 & 調布店 & 合計 \\
\hline 4月 & 153 & 91 & 121 & 89 & 247 & & 93 & 91 & 76 & 56 & 40 & 73 & 127 & 1,257 \\
\hline 5月 & 177 & 117 & 150 & 71 & 197 & & 93 & 84 & 87 & 64 & 44 & 75 & 120 & 1,279 \\
\hline 6月 & 153 & 120 & 134 & 96 & 263 & & 105 & 71 & 65 & 57 & 36 & 94 & 127 & 1,321 \\
\hline 7月 & 147 & 88 & 129 & 86 & 211 & & 73 & 59 & 90 & 51 & 25 & 86 & 119 & 1,164 \\
\hline 8月 & 101 & 64 & 69 & 45 & 177 & & 57 & 70 & 58 & 40 & 30 & 60 & 78 & 849 \\
\hline 9 月 & 173 & 90 & 115 & 52 & 266 & & 93 & 72 & 73 & 42 & 39 & 87 & 122 & 1,224 \\
\hline 10 月 & 213 & 134 & 149 & 104 & 227 & 144 & 126 & 87 & 115 & 58 & 44 & 139 & 172 & 1,712 \\
\hline 11 月 & 200 & 135 & 155 & 91 & 218 & 128 & 82 & 73 & 94 & 56 & 49 & 99 & 139 & 1,519 \\
\hline 12 月 & 173 & 106 & 137 & 90 & 151 & 118 & 85 & 97 & 91 & 72 & 45 & 90 & 107 & 1,362 \\
\hline 1月 & 153 & 101 & 95 & 76 & 123 & 75 & 60 & 85 & 59 & 49 & 43 & 54 & 101 & 1,074 \\
\hline 2月 & 119 & 66 & 117 & 54 & 150 & 83 & 56 & 66 & 59 & 39 & 32 & 58 & 103 & 1,002 \\
\hline 3月 & 126 & 118 & 125 & 77 & 191 & 76 & 56 & 86 & 82 & 46 & 44 & 71 & 99 & 1,197 \\
\hline 合計 & 1,888 & 1,230 & 1,496 & 931 & 2,421 & 624 & 979 & 941 & 949 & 630 & 471 & 986 & 1,414 & 14,960 \\
\hline
\end{tabular}

*千歳船橋店は 10 月から 2 チーム体制をとる (1)は月火水土，(2)は木金日を担当）

2008 年度店舗別来店者数

表 2 年間延来店者数

\begin{tabular}{|c|c|c|c|c|c|c|c|c|c|c|c|c|c|c|}
\hline & 町店 & 馬店 & 石神井 & 江戸川 & 千船(1) & 千船(2) & 大店 & 池尻店 & 昭島店 & 田無店 & 多摩店 & 八王子 & 調布店 & 合計 \\
\hline 4 月 & 715 & 975 & 790 & 636 & 1,676 & & 792 & 629 & 718 & 624 & 575 & 1,057 & 591 & 9,782 \\
\hline 5月 & 680 & 879 & 820 & 605 & 1,284 & & 803 & 544 & 88 & 575 & 490 & 823 & 68 & 8,979 \\
\hline 6月 & 76 & 971 & 915 & 554 & 1,897 & & 834 & 532 & 843 & 07 & 513 & 860 & 88 & 10,077 \\
\hline 7月 & 701 & 875 & 805 & 494 & 1,764 & & 815 & 565 & 862 & 617 & 466 & 852 & 743 & 9,559 \\
\hline 8月 & 517 & 632 & 665 & 345 & 1,343 & & 640 & 414 & 540 & 387 & 412 & 613 & 20 & 7,082 \\
\hline 9月 & 692 & 781 & 734 & 403 & 1,875 & & 797 & 461 & 764 & 511 & 449 & 770 & 10 & 8,847 \\
\hline 10 月 & 884 & 992 & 1,011 & 760 & 1,354 & 1,054 & 955 & 575 & 921 & 689 & 553 & 1,260 & 796 & 11,804 \\
\hline 11月 & 711 & 881 & 991 & 616 & 1,085 & 807 & 865 & 562 & 705 & 666 & 412 & 908 & 2 & 9,911 \\
\hline 12 月 & 640 & 962 & 859 & 500 & 1,060 & 713 & 778 & 539 & 755 & 626 & 450 & 822 & 565 & 9,269 \\
\hline 1 月 & 576 & 777 & 759 & 487 & 1,174 & 736 & 657 & 487 & 655 & 529 & 424 & 622 & 547 & 8,430 \\
\hline 2月 & 592 & 762 & 791 & 442 & 1,077 & 749 & 745 & 575 & 622 & 501 & 403 & 570 & 582 & 8,411 \\
\hline 3月 & 767 & 933 & 921 & 530 & 1,309 & 690 & 741 & 572 & 676 & 566 & 484 & 750 & 690 & 9,629 \\
\hline 合計 & 8,238 & 10,420 & 10,061 & 6,372 & 16,898 & 4,749 & 9,422 & 6,455 & 8,869 & 6,998 & 5,631 & 9,907 & 7,902 & 111,780 \\
\hline
\end{tabular}

*千歳船橋店は 10 月から 2 チーム体制をとる (1)は月火水土, (2)は木金日を担当) 


\section{表 3 エコメッセ練馬 3 店の年間売り上げ数}

2008 年度各店月別売上表

\begin{tabular}{|c|c|c|c|c|c|c|c|c|}
\hline & 4月 & 5月 & 6月 & 7 月 & 8月 & 9 月 & & \\
\hline 関町 & 399,645 & 409,405 & 417,280 & 385,050 & 374,070 & 394,730 & & \\
\hline 練馬 & 475,350 & 406940 & 457,430 & 401,050 & 280,629 & 344,540 & & \\
\hline \multirow[t]{2}{*}{ 石神井 } & 429,585 & 428,685 & 560,645 & 466,670 & 356,850 & 402,970 & & \\
\hline & 10 月 & 11月 & 12 月 & 1 月 & 2 月 & 3 月 & 合計 & 平均 \\
\hline 関町 & 492,290 & 420,680 & 481,300 & 339,280 & 331,233 & 438,470 & $2,380,180$ & 396,697 \\
\hline 練馬 & 468,730 & 460,590 & 464,100 & 361,470 & 334,940 & 434,185 & $2,365,939$ & 394,323 \\
\hline 石神井 & 606,270 & 611,535 & 509,315 & 444,995 & 380,425 & 488,195 & $2,645,405$ & 440,901 \\
\hline
\end{tabular}

一旦家庭からもらった衣類はすでに事業のための品物で, 処分するときは産業廃棄物となる。そこで独自のルート を開発しわれわれの NPO を超えた衣類の循環システム を作る必要に迫られた。回収業者を選ぶときにも，まず は回収されたものがその後どうなるのかが気になる。

最初にあたった産廃業者は集めたものは燃やすとの答 えで，これには同意できなかった。次に生協が委託して いた古布回収の業者に連絡をとり, 集めた古布がウエス やパッキング材料として, 再びリサイクルされている業 者に㹉いし回収してもらうことになった。次の年にも， また展示できそうな衣類は保管している。エコメッセは 現在（2010 年 3 月末）東京都内に 13 店舗あり, 全店舗 で使う大きな倉庫を持って, そこに季節外のものを保管 し，他店に回す中継地にしている。

現在は古布回収のルートとして不登校の子ども達を支 えるNPOへのルートも, 地域の連携としてできた。ま たエコメッセ内で, 使えるものに再生するリメイクチー ムを作り, マフラー, エプロンなどを製作, 販売してい る。なるべく使い切りたいとの思いからであるが, 事業 としてどこまで採算が合うのかこれからの課題でもある。 参考までに表 3 にエコメッセ練馬 3 店の年間売り上げ数

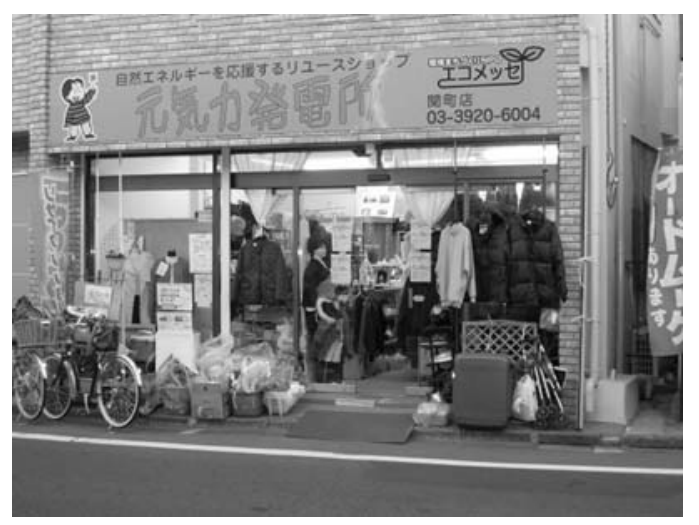

図 1 現在の関町店

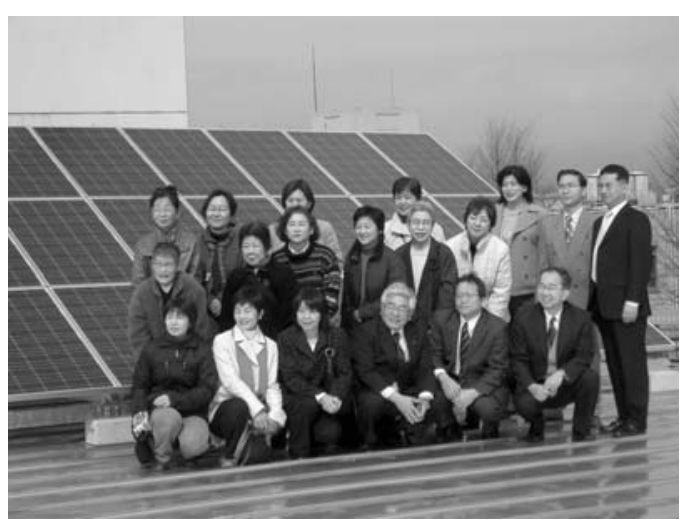

図 2 市民発電所 1 号機『武蔵』武蔵大学 5 号館 パネ ル前で記念撮影

5号館屋上で太陽光発電パネルによる

\section{市民発電所 1 号㙨「武蔵」}

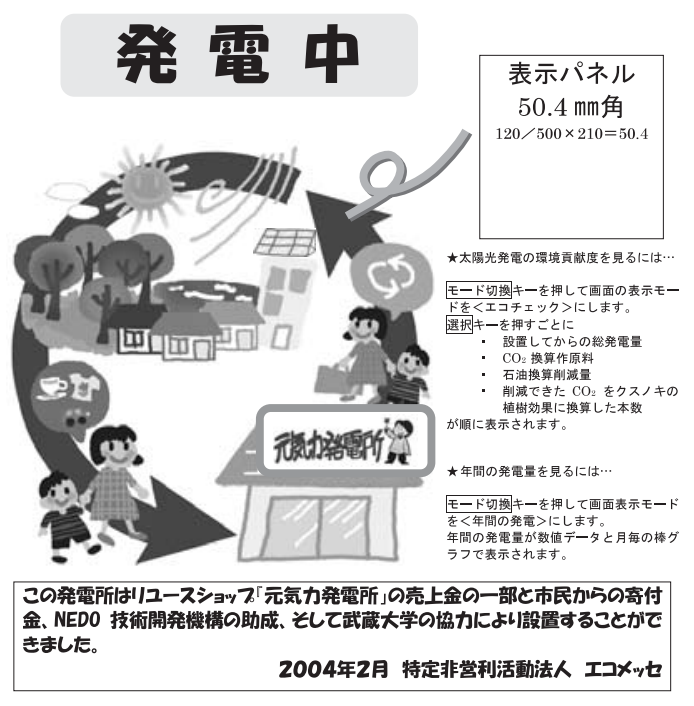

図 3 市民発電所 1 号機『武蔵』の計測機と表示板 


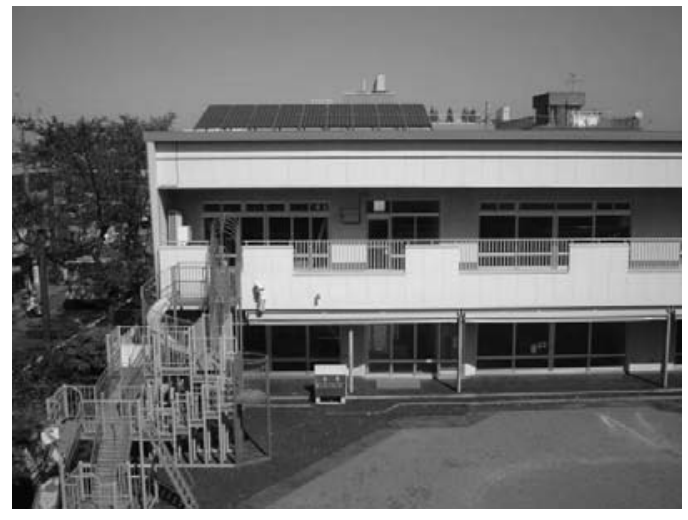

図 4 市民発電所 2 号機『双葉』大泉双葉幼稚園

を示しておく。

\section{4. 最 後 に}

大量生産，大量消費が豊かさだと考えられた時代を経 て，持続可能が叫ばれ，今また良いものを大事にという ことを考える人たちが増えているのではないかと思う。 衣類の素材一つとっても，人に優しく、リユース, リサ イクル，リメイクしやすいのは天然繊維である。われわ れの店で売れやすいのも，そういった素材のものである (図 1 参照)。最後の最後まで地域全体で端切れなどとし て使って, 衣類, 繊維類もごみとして出されるのをゼロ にしていきたいものである。

リユースショップ『元気力発電所』の売上で作った市 民発電所は 3 号機までできた（図 2 5)。拈店で「皆さ んの寄付と抄買い上げでできた皆さんの発電所です」と 来店者の皆さんに報告をしている。

ソーラークッカーによる環境学習授業（図 6) や緑の

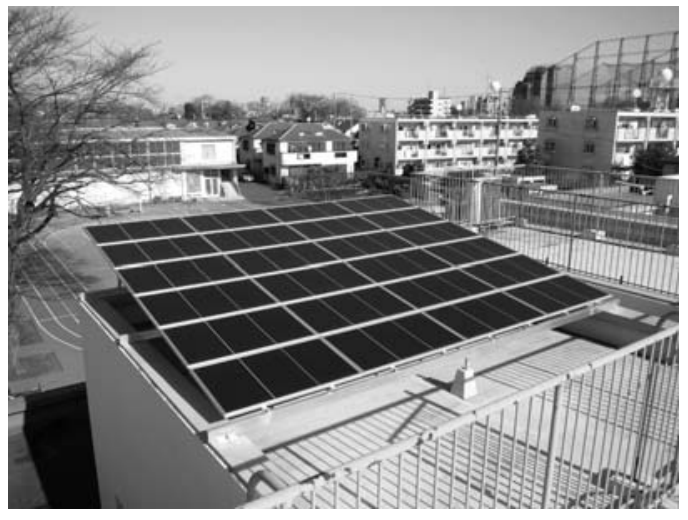

図 5 市民発電所 3 号機『三育』東京三育小学校

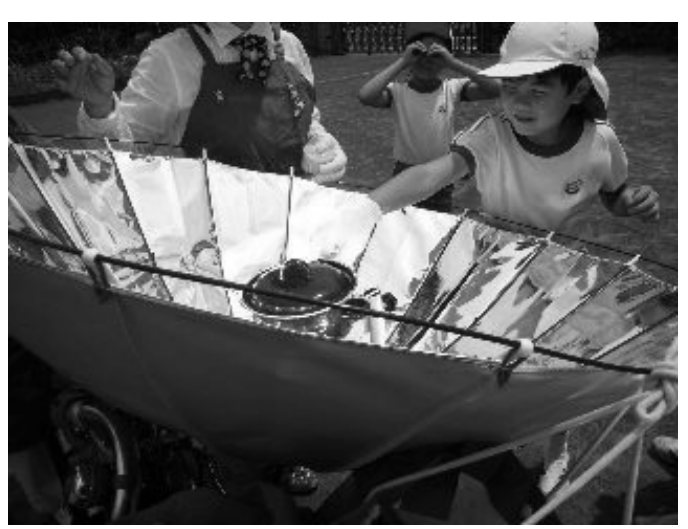

図 6 小学校の環境授業

カーテン作りによる省エネルギーの提案など，身近な地 域で目に見える活動を目指してゆくつもりである。 合い言葉は「エネルギーも食べものも地産地消」。 